\title{
Mediastinal Germ Cell Tumor TX TNM
}

Finding

National Cancer Institute

\section{Source}

National Cancer Institute. Mediastinal Germ Cell Tumor TX TNM Finding. NCI Thesaurus.

Code C146831.

Primary tumor cannot be assessed. (WHO Classification of Tumors of the Lung, Pleura,

Thymus and Heart, 2015) 